\title{
DETERMINIG THE PROFILE OF TOURISTS AS USERS OF RURAL TOURISM PRODUCT- FOCUS ON A DEVELOPING AREA (VOJVODINA PROVINCE)
}

\section{UTVRĐIVANJE PROFILA TURISTA KAO KORISNIKA RURALNOG TURISTIČKOG PROIZVODA- FOKUS NA RAZVOJNOM PODRUČJU (POKRAJINA VOJVODINA)}

\author{
Tamara GAJIĆa, Marko D. PETROVIĆb, Milan RADOVANOVIĆc, Julia A. \\ SYROMIATNIKOVA ${ }^{\mathrm{d}}$, Dunja DEMIROVIĆ BAJRAMI ${ }^{\mathrm{e}}$
}

\footnotetext{
a Geographical Institute "Jovan Cvijić", Serbian Academy of Sciences and Arts, Belgrade, Serbia and Institute of Sports, Tourism and Service, South Ural State University, Chelyabinsk, Russian Federation*, e-mail: tamara.gajic.1977@gmail.com

b Geographical Institute "Jovan Cvijić", Serbian Academy of Sciences and Arts, Belgrade, Serbia and Institute of Sports, Tourism and Service, South Ural State University, Chelyabinsk, Russian Federation, e-mail: m.petrovic@gi.sanu.ac.rs

c Geographical Institute "Jovan Cvijić", Serbian Academy of Sciences and Arts, Belgrade, Serbia and Institute of Sports, Tourism and Service, South Ural State University, Chelyabinsk, Russian Federation, e-mail:m.radovanovic@gi.sanu.ac.rs

d South Ural State University, Institute of Sports, Tourism and Service, Chelyabinsk, Russian Federation, e-mail: syromjatnikowa@mail.ru

e Geographical Institute "Jovan Cvijić", Serbian Academy of Sciences and Arts, Belgrade, Serbia and Institute of Sports, Tourism and Service, South Ural State University, Chelyabinsk, Russian Federation, mail: d.demirovic@gi.sanu.ac.rs
}

Cite this article: Gajić, T., Petrović, D.M., Radovanović, M., Syromiatnikova, J., Demirović Bajrami, D. (2021). Determinig the Profile of Tourists as Users of Rural Tourism Product- Focus on a Developing Area (Vojvodina Province). Deturope, 13(1), 39-57.

\begin{abstract}
Rural tourism seems to be an appropriate means of revitalizing abandoned rural areas and ensuring their sustainability in the future through job preservation or job creation. The Vojvodina Province (Northern Serbia) has very good resource potentials in rural tourism, but in order for rural tourist products to become competitive, it is necessary to work on the segmentation of the tourism market or consumer profiling. The primary purpose of this study is to investigate the profiles of tourists, motivational factors that most influence the choice of rural tourism. The research was conducted in the traditional rural surroundings, on a sample of 491 respondents. A modified questionnaire was used, in which the basic motives were grouped into six market segments, and based on CFA analysis, in the software, SPSS Amos, version 21.00, the authors confirmed the hypothetical structure of factors, and the causal relationship of manifest variables and latent dimension rural tourism. More precisely, it has been established what the key motives that identify rural tourism in Vojvodina are. The research results showed that rest, or relaxation in nature with learning, are the main motives for visiting rural areas of Vojvodina. By segmenting the tourist users of rural tourism, it was determined that most of those tourists come for relaxation.
\end{abstract}

Keywords: development, rural tourism, consumer profiling, motivation, Vojvodina

\begin{abstract}
Čini se da je seoski turizam odgovarajuće sredstvo za revitalizaciju napuštenih ruralnih područja i osiguravanje njihove održivosti u budućnosti kroz očuvanje radnih mesta ili otvaranje novih radnih mesta.
\end{abstract}


Pokrajina Vojvodina (Severna Srbija) ima vrlo dobre resursne potencijale u seoskom turizmu, ali da bi seoski turistički proizvod postao konkurentan, potrebno je raditi na segmentaciji turističkog tržišta ili profilisanju potrošača. Primarna svrha ove studije je da istraži profile turista, motivacijske faktore koji najviše utiču na izbor seoskog turizma. Istraživanje je sprovedeno u tradicionalnom ruralnom okruženju, na uzorku od 491 ispitanika. Korišćen je modifikovani upitnik u kojem su osnovni motivi grupisani u šest tržišnih segmenata, a na osnovu analize CFA, u softveru, SPSS Amos, verzija 21.00, autori su potvrdili hipotetičku strukturu faktora i uzročno-posledičnu vezu manifestnih promenljivih i latentne dimenzije ruralni turizam. Tačnije, utvrđeno je koji su ključni motivi koji identifikuju seoski turizam u Vojvodini. Rezultati istraživanja pokazali su da su odmor, ili opuštanje u prirodi uz učenje, glavni motivi za posetu ruralnim područjima Vojvodine. Segmentiranjem turističkih korisnika seoskog turizma utvrđeno je da većina tih turista dolazi radi opuštanja.

Ključne reči: razvoj, ruralni turizam, profilisanje potrošača, motivacija, Vojvodina.

\section{INTRODUCTION}

The area of Vojvodina, as an Autonomous Province in the Republic of Serbia, is 21,614 km², with a total of 467 settlements and 1,881,357 million inhabitants (Petrović et al., 2017). In the structure of GDP of Autonomous Province of Vojvodina, industry represents 53.4\%, services with $30 \%$, agriculture with about $10 \%$, and construction with $6.9 \%$, while GDP per capita in rural areas is $74 \%$ of the national average (Cvijanović et al., 2020). The agricultural population of Autonomous Province of Vojvodina makes up $26 \%$ of the active agricultural population of Serbia (Petrović et al., 2018). There is 0.88 hectares of arable land per capita. If we take into account that the average farm size is about 3.59 ha of arable land and that each farm has about three separate plots, it can be concluded that Autonomous Province of Vojvodina has a very unfavorable property structure (Andrić et al., 2010). Rural tourism is already developed in some parts of Vojvodina, but the position it occupies in the tourist market is insufficient, especially if the rich resource base and geographical position are taken into account.

The development of rural tourism in Autonomous Province of Vojvodina can play an important role in increasing the diversity of the tourist offer all over the Serbia and forming a richer image of the country. On the other hand, tourism in the villages of Vojvodina should not only be a goal, but also a means to stimulate economic growth, strengthen underdeveloped regions and improve the living standards of the local population. In Autonomous Province of Vojvodina, the fact is known about the increase in poverty in the countryside and the departure of people from those areas (Novković et al., 2013). With the development of tourism, multifunctional agriculture is emerging, which gives people in the villages additional opportunities for economic strengthening. With its natural and social wealth, Vojvodina has all the predispositions to be on the list of regions with developed rural tourism. According to the Tourism Development Strategy of the Republic of Serbia, rural tourism is one of the key 
types of tourism in Autonomous Province of Vojvodina, it is in the Regional Spatial Plan of Autonomous Province of Vojvodina until 2025. It should not be forgotten that in Vojvodina, tourism in rural areas is related to agriculture (Gajić et al., 2018). What is one big unknown in the rural tourism development in Vojvodina, is the market segmentation or profiling of tourists, more precisely what are the motivators that imply going to the villages and using the rural tourism product. Previous research has not taken into account the motivational segmentation of the rural tourism market (Blešić et al., 2014). Most of the research studies found on this topic dealt with the knowledge of the impact of the local population on rural development, and the quality of services provided in these parts of Vojvodina. However, world research explains the importance of market segmentation and profiling much more, and there is more research on this issue.

The aim of this research is to determine the target market or profile of a tourist visiting rural areas in Vojvodina. A standardized model of the questionnaire, which was used by Park and Yoon (2009), in their paper Segmentation by motivation in rural tourism: A Korean case study. In their work, using Principal component analysis (PCA), they grouped certain motivators into six factor groups, and determined their influence on the selection of a rural tourism product. After that, with the help of cluster analysis, they identified four segmentation groups of tourists. They came to the conclusion that the motive for relaxation is one of the main motives for visiting the villages of Korea. The authors of this paper modified the questionnaire, taking over the six obtained factors, and determined which of the motivating factors can be the profile of the tourist who decides to visit the villages of Vojvodina. With the help of an appropriate statistical analysis, CFA, they confirmed the given factor structure, and further determined the strength of the influence of manifest variables on latent variable rural tourism. The only limitation in the research was the fact that all respondents were domestic visitors. The sample of persistence did not include foreigners. During the research period in the rural areas of Vojvodina, there were no foreign tourists. During the whole year, 64.153 domestic and 125.432 foreign visitors were recorded in the city of Novi Sad. Their visit focused on the city, a very small and short stay in the countryside.

Given the small amount of research on the topic of profiling rural tourists in Vojvodina, and the segmentation of the tourist market, this research work will help determine groups of existing and potential consumers. This will enable a better understanding of the needs and desires of consumers and the perception of personal, situational and behavioral features of the segment. The tourist product should be completely adjusted to the wishes and needs of a certain market segment, ie. specialize and focus on a specific market segment. Therefore, this 
study aims to understand travel motivations and characteristics of tourists visiting a rural destination to provide a better understanding of rural tourism in the Vojvodina. However, it should be noted that the selection of the target segment also determines the position of the product on the market. The process of motivational segmentation leads to product positioning in the market. This result of segmentation analysis is, in a competitive market, a form of exploitation of segmentation analysis and its transformation into a strategy, given that the possibility of independent selection on the consumer, and to offer them their product.

\section{THEORETICAL BACKGROUND}

Some estimates indicate that about $65 \%$ of the total world tourist demand is directed towards natural values and spaces, it is impossible to determine more precisely how much of that huge world tourist wave flows to rural areas (Jing, 2006; Petrović et al., 2018). Many works of literature show the importance of rural tourism in the world: it increases employment, affects the expansion of entrepreneurial activities, reduces poverty, affects the return of people from cities to villages, points to the use and promotion of natural resources, affects economic profit, expands social and cultural influence, increases the building of infrastructure capacities, participation in decision - making by the government and the private sector, increase of collective revenues (Hall et al., 2003; Çiğdem et al., 2020). However, many authors discuss whether and to what extent the development of rural tourism is important for the economy (Sharpley, 2000; Canoves et al., 2004; Dissart et al., 2009). Visitors to rural areas very often do not do any activities, except rest and relaxation (Park et al., 2009). Rural development covers a very wide range, primarily economic activities, as the basis of development, and this is emphasized in villages and rural areas (Flisher et al., 2000; Pesonen, 2013). The fact is that no country can survive without rural development. In recent years, there has been increasing research against rural tourists, who use the product in a completely different way, and come up with a whole new attitude about understanding the rural environment and its values (Frochot, 2005; Pesonen, 2012; Rid et al., 2015). Frochot (2005), describes in detail all the activities that can be done in villages, and defines the term rural tourist. Lane and Kastenholz (2015), represent rural tourism in the form of umbrellas, which encompassing many different specific types of tourism. Jing (2017), points to the great importance of rural tourism, which solves all social and economic problems that arise in a conventional agricultural industry. Rural tourism attracts with its space and natural resource base (Roberts et al., 2001; Lane et al, 2015; Jing et al., 2018). 
The fact is also that the issue of rural tourism development in Vojvodina is completely neglected, which leads to catastrophic situations (Gajić et al., 2018). All Serbian villages and rural areas are as potential resources for rural development, evidently proven and undisputed. For determining successful destination marketing strategies, professional organization by activities is of great importance (Petrović et al., 2018). The starting point for each activity are projects, on various topics and with only one common basis, rural development as an essential goal that brings in realization and literally salvation for an active rural environment. Projects for rural development of rural areas of Vojvodina, primarily refer to investments in infrastructure, communal equipment, and the economy, thanks to natural potentials as preconditions, looking for space in renewable energy (Cvijanović et al., 2020). How and to what extent the factors influence the decision-making process on the purchase of a rural tourist product can be obtained only if extensive research is conducted. Every consumer strives to buy the product / service that represents value to him (Zhang et al., 2019). The category of value is related to the type of personality, so that the same product can be evaluated differently by different consumers. The destination must be positioned appropriately and build a prestigious brand in the minds of consumers, in a highly competitive environment. Numerous world researches show the importance of motivation in choosing a tourist product and market segmentation (Crompton, 1979; Dann, 1981; Yuan et al., 1990; Uysal et al., 1994; Fodness, 1994; Cha et al., 1995; Hanqin et al., 1999; Zhang et al., 1999; Nicholson et al., 2001; Kozak, 2002; Josiam et al., 2004; Bansal et al., 2004). For determining successful destination marketing strategies, it is important to understand the interactions between pull and push factors related with that specific destination (Kim et al., 2002; Kelliher et al., 2018). Formica (1998) also emphasized the importance of examining motivation in a better understanding of tourism development, both an economic and a social phenomenon. According to Iso Ahola (1982), a visit to a tourist place is motivated by an escape from everyday life. Similar to his research, Pearce and Lee (2005) continue by pointing out that in addition to running away from everyday life, the motive for traveling is to relax as well as improve relationships. Jang and $\mathrm{Wu}$ (2006) found in their research that travel stems from the desire for family togetherness and socializing, as well as relaxation. In their presentation (2015), Rid, Ezeuduji and Pröbstl-Haider, established the following tourist profile on a sample of 430 respondents in The Gambia: multi-experiences \& beach seekers, multi-experiences seekers, heritage \& nature seekers, sun \& beach seekers. Different descriptors and discriminating variables to segment a market have often been addressed in the literature: benefits sought by travelers (Loker et al., 1992; Wight, 1996), product bundles (Oh et al., 
1995; Lee et al., 2004), attributes for vacation, motivations (Loker-Murphy, 1996), behavioral characteristics (Formica et al., 1998; Mok et al., 2000, Song, 2005). That market segmentation and consumer profiling is the basis for identifying homogeneous groups was argued by Beane and Ennis in their 1987 study, entitled Market Segmentation. Identifying tourism markets for different tourism products is necessary to achieve long-term business and competitiveness in the tourism market (Frochot, 2005; Walker et al., 2006; Molera et al., 2007; Ezeuduji et al., 2011). Sharpley (2000) states that demography is a key factor in market segmentation, and other factors such as economic status and age are less predictors of rural tourism development. Johns and Gyimothy (2002), gave serious criticisms of the segmentation of the tourism market, because they came to the conclusion that this procedure did not identify real consumers. A large number of theorists claim that there are four market segments (Cha et al., 1995; Kim et al., 2002; Sorigo et al., 2005; Snyman et al., 2012), while very few look at just one segmentation. According to Carter, Wei and Ruys (2002), segmentation relies on psychographic and demographic factors to identify six senior traveler segments that holiday in Australia. Sarigollu and Huang (2005), presented a segmentation based solely on the geographical factor in the Region of Latin America, on a total sample of 265 surveyed visitors. Based on psychographic factors, market segmentation was performed by Scott and Parfitt (2004), in the Region of Tropical North Queensland (Australia) to a total of 877 respondents. Moscardo (2004), investigates market segmentation in the Region of Cairns (Australia) to 1630 respondents, where he found that two factors are most important in this process: demographic and geographical.

\section{METHODOLOGY}

The research was conducted in the villages of Vojvodina, with the aim of researching the motive of the trip or the profile of the tourist, in order to more easily understand the position of rural tourism in Vojvodina on the tourist market. The research was conducted in the period between May and October 2019. All 491 participants in the research were domestic tourists, which is the main fact that characterizes the rural tourist product of Vojvodina, and the main limitation. The first phase of the research involved collecting relevant literature on a given topic, and studying existing research in the world. All facts are supported by statistical data and available documentation, which increases the importance and seriousness of the research work and the overall content of the paper. The second part of the research included a survey on a sample of 491 respondents. A modified questionnaire (with a total of 24 group questions 
in 6 factors) was used by Park and Yoon (2009) in their study, in a paper entitled Segmentation by motivation in rural tourism: A Korean case study. In their research model, the questions were grouped into six factors, with the help of Principal component analysis (PCA), after which they clustered the market into four clusters, and determined the segmentation groups or profiles of tourists who mostly visit rural areas. The authors of this paper used already existing factors with set items, and based on CFA analysis, confirmed the factor grouping, and determined which of the above factors most identifies the rural tourism, using SPSS AMOS software, version 21.00. Confirmatory factor analysis (CFA) is a type of structural modeling (SEM) that is often used in applied research, where the relationship between measurable variables is checked. The validity of a measurement model depends on determining acceptable levels of good competence for the measurement model and finding specific evidence of the validity of the construct. Validity is defined as the extent to which data collection methods accurately measure what they are intended to measure (Saunders and Thornhill, 2003). To meet the validity process, validation and reliability checks were performed: Content validity, Convergent validity, Composite Reliability, Discriminant Validity, Nomological Validity. Table 1 shows the values of the suitability index. Absolute fit indices estimate how well the model reproduces the data from the sample: CFI (Goodness-ofFit), RMSEA (Root-mean-square error of approximation), NFI (Normed fit index), TLI (Tucker-Lewis Index). Absolute fit indices show values within the normal range.

Table 1 Fit statistics of the measurement model

$\begin{array}{ccc}\text { Fit statistic } & \text { Recommended } & \text { Obtained } \\ \text { CFI } & >0,90 & 0.983 \\ \text { RMSEA } & <0,05 & 0.047 \\ \text { NFI } & >0,90 & 0.946 \\ \text { TLI } & >0,90 & 0.972\end{array}$

Source: author's research

After the validation of the measuring instrument was satisfied, the results of the confirmed factor analysis (CFA) using Amos 21 were used to assess the adjustment of the measuring model. The hypothetical factor structure was confirmed with the help of CFA analysis, and the validation procedure in the measurement model was performed. CFA implies the application of SEM technique (Structural Equation Modeling. Through this technique, through graphical modeling and combining statistical methods, CFA is realized. The main 
goal of CFA is to define causal connections of manifest variables and factors, i.e., latent dimensions (George et al., 2003).

\section{RESULTS AND DISCUSSION}

A total of $56.6 \%$ of men and $43.4 \%$ of women participated in the study. Of these, a total of $16.7 \%$ belonged to the age group under 25 years, $26.3 \%$ in the range between 25 and 40 years, $41.8 \%$ to the age group from 41 to 60 years. A total of $15.2 \%$ belonged to the group of respondents over 60 years of age. Regarding the level of earnings of respondents who visited the rural areas of Vojvodina, $17.7 \%$ of them have incomes below 200 e, $69.9 \%$ in the range of 200 to 400 EUR, and $12.4 \%$ with earnings of over 400 EUR per month. The research included a total of $31 \%$ of students surveyed with high school graduation, and $69 \%$ with higher education at the faculty and the like. The number of variables in the model is 56, of which unobserved variables 32 , and observed variables 24 . The number of exogenous is 25 , while exogenous variables are 31 (independent of other variables).

Figure 1 Graphical representation of the CFA model (*R.T.P- rural tourism product)

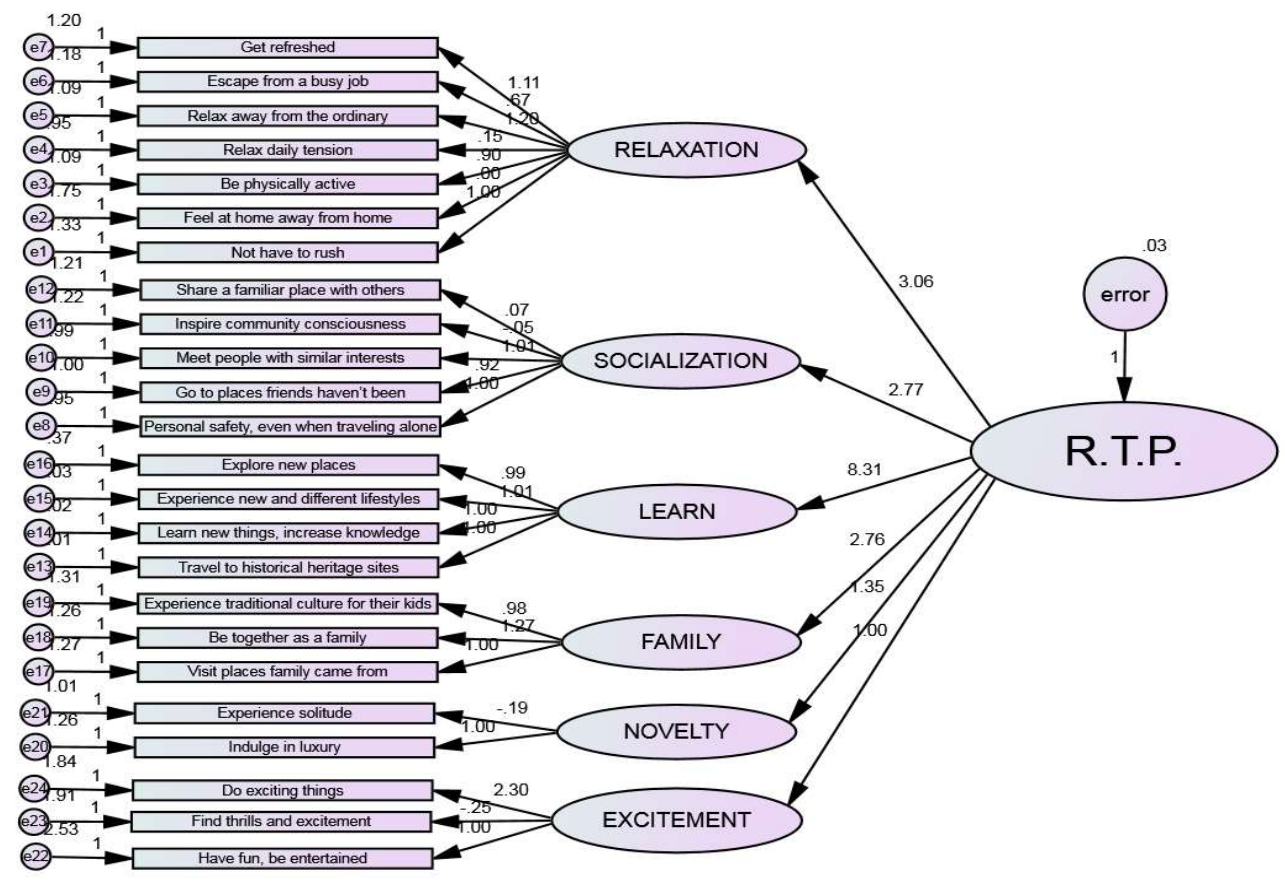

The $\chi^{2}$ test yields a value of 8.351 which, evaluated with 252 degrees of freedom, has a corresponding p-value of 0.00 . This p-value is too high to reject the null of a good fit. Chi square is an observation of a random variable that has an approximate chi distribution with 
252 degrees of freedom. The graph shows items, manifest variables, as well as the latent variable rural tourism product. Standardized factor loads, values of direct and indirect effects, as well as errors, are shown in the graph. Table 2. gives an overview for Regression Weights (Estimate, S.E, C.R).

Table 2 Regression Weights

\begin{tabular}{lcccc}
\multicolumn{1}{c}{ Covariances } & Estimate & S.E & C.R & P \\
\hline Relaxation <---R.T.P & 3.06 & 1.31 & 2.33 & 0,02 \\
\hline Socialization <----R.T.P & 2.77 & 1.18 & 2.34 & 0,01 \\
Learning <----R.T.P & 8.31 & 3.46 & 2.39 & 0,01 \\
Family <----R.T.P & 2.76 & 1.18 & 2.32 & 0,02 \\
Novelty <---R.T.P & 1.35 & 0.63 & 2.12 & 0,03 \\
Excitement <----R.T.P & 1.00 & - & - & - \\
\hline
\end{tabular}

Source: author's research. $*$ S.E $=$ standard covariance error ; C.R $=$ Critical Ratio; $\mathrm{P}=\mathrm{p}-$ statistical significance; R.T.P rural tourism product

Relaxation implies the release of any physical and mental tension, and is one of the key motives for choosing a rural holiday environment. A total of 7 items belonged to this factor. It is observed that there is statistical significance in the influence of relaxation factors on R.T.P. The first covariance between relaxation variables and R.T.P is estimated to be 3.06 , with an estimate of the standard covariance error S.E $=1.31$. Estimate 3.06 is an observation of an approximately normally distributed random variable centered around the covariance of a population with a standard deviation of 1.31 . These figures serve to construct a $95 \%$ confidence interval on the covariance population by calculating Estimate and S.E. The Critical Ratio (C.R) was obtained by dividing the covariance estimate by its standard error. At a statistical significance of $\mathrm{p}<0.05$, any C.R exceeding 1.96 is considered significant. If this value is achieved, it is considered that the covariance between the variables differs significantly from 0 , at the level of significance $p<0.05$. It is noticed that this value is above than 1.96 , therefore it can be concluded that the relaxation significantly affect the variable R.T.P. A large P in addition to C.R gives about two tailed $p$ values to test the hypothesis. In this case, the covariance between the variables differs from 0 , with $p=0.2$. Calculation $P$ implies that parameter estimates are normally distributed, and are accurate only in large samples. The term socialization is widely used in explaining the motives of travel. Socialization is a permanent learning process during which we adopt the norms and rules of our culture, and we become able to participate in social relations. In the original questionnaire, as well as in the modified form, the socialization factor included a total of five 
items. For the socialization variable, the covariance value is estimated to be 2.77 , with a standard error estimate of $\mathrm{S} . \mathrm{E}=1.18$. The C.R value is 2.34 , which is greater than 1.96 , and is considered significant, which is confirmed by the value of $p$, which is 0.01 . These data indicate that socialization has an impact on the decision to choose rural tourism products. Travel has always been motivated by the learning factor, spreading knowledge by getting to know new places. The learning motive is one of the key motives in choosing a trip, and in this research it contains a total of four items. The estimate of the third covariance between learning and R.T.P, is very high 8.31, with a standard error estimate of S.E 3.46. Critical Ratio (C.R) is 2.39 , with a value of $\mathrm{p}<0.05$, and the level of learning motive is correlated with the decision for rural tourism products. The motive of the trip, which refers to the expansion of family relations, and getting to know the origin of the family and staying in nature, hanging out with the closest ones, contains three items. Covariance family has estimate about 2.76 , with $\mathrm{S} . \mathrm{E}=1,18$, and C.R $=2.32$. The data indicate that the family motive has a significant influence on the decision to choose a rural tourist product $(p=0.02)$. The reasons for traveling to a rural tourist environment can be from family needs. Novelty is also a set of motive that play a significant role in the selection of R.T.P (estimation $=1.35$; S.E $=$ $0.63 ; \mathrm{C} . \mathrm{R}=2.12 ; \mathrm{p}=0.03)$. The results show that covariance excitement does not make a significant contribution in motivating tourists to choose to visit rural areas.

The Standardized Regression Weights can be interpreted as the correlation between the observed variable and the corresponding common factor. All six variables have moderate to strong standardized loadings on factor (1.000). They all are reliable indicators for rural value. Looking variable relaxation, item Relax away from the ordinary, has the strongiest standardized loadings on relaxation, and the estimate is 0,519, but item Feel at home away from home, has very low standardized loadings on factor (0.00). Item Inspire community consciousness, has very low estimate, but Personal safety, even when traveling alone, has estimate about 0.440 . Items learning have very strong standardized loadings on factor learning. Every item has estimate above 0.99. Items family have low estimates on factor family. Novelty items, have low standardized loadings on factor novelty. The Standardized Regression Weights of item Find thrills and excitement has estimate of -0.31 , what means that item has low standardized loadings on factor excitement. Also other items have low loadings on factor. 
Table 3 Standardized Regression Weights

\begin{tabular}{|cc} 
& Estimate \\
\hline RELAXATION <---R.T.P & 1.000 \\
\hline SOCIALIZATION <---R.T.P & 1.000 \\
\hline LEARNING <----R.T.P & 1.000 \\
\hline FAMILY < ---R.T.P & 1.000 \\
\hline NOVELTY < ---R.T.P & 1.000 \\
\hline Not have to rush <---RELAXATION & 0.418 \\
\hline Feel at home away from home < --- RELAXATION & 0.000 \\
\hline Be physically active <--- RELAXATION & 0.415 \\
\hline Relax daily tension <--- RELAXATION & 0.082 \\
\hline Relax away from the ordinary <--- RELAXATION & 0.519 \\
\hline Escape from a busy job <--- RELAXATION & 0.310 \\
\hline Get refreshed <--- RELAXATION & 0.471 \\
\hline Personal safety, even when traveling alone <---SOCIALIZATION & 0.440 \\
\hline Go to places friends haven't been <--- SOCIALIZATION & 0.401 \\
\hline Meet people with similar interests <--- SOCIALIZATION & 0.434 \\
\hline Inspire community consciousness <--- SOCIALIZATION & -0.021 \\
\hline Share a familiar place with others <--- SOCIALIZATION & 0.031 \\
\hline Travel to historical heritage sites <---LEARNING & 0.997 \\
\hline Learn new things, increase knowledge <---LEARNING & 0.996 \\
\hline Experience new and different lifestyles <---LEARNING & 0.993 \\
\hline Explore new places <---LEARNING & 0.919 \\
\hline Visit places family came from <---FAMILY & 0.389 \\
\hline Be together as a family <--- FAMILY & 0.473 \\
\hline Experience traditional culture for their kids <--- FAMILY & 0.377 \\
\hline Indulge in luxury <---NOVELTY & 0.203 \\
\hline Experience solitude <---NOVELTY & -0.044 \\
\hline Have fun, be entertained <---EXCITEMENT & 0.108 \\
\hline Find thrills and excitement <--- EXCITEMENT & -0.031 \\
\hline Do exciting things <--- EXCITEMENT & 0.281 \\
\hline
\end{tabular}

Source: author's research.*R.T.P rural tourism product

The squared multiple correlations provide information on how much variance the common factors account for in the observed variables, despite receiving a path from both latent variables. In addition, the $\mathrm{R}^{2}$ corresponding to 14 of the 24 observed variables indicate that the respective factor explains a respectable portion of the variance (between 14.2\% and 99.4\%). The remaining $\mathrm{R}^{2}$ statistics are, in order of increasing magnitude: Explore new places $\left(\mathrm{R}^{2}=0.844\right)$, Experience new and different lifestyles $\left(\mathrm{R}^{2}=0.987\right)$, Learn new things, increase knowledge $\left(\mathrm{R}^{2}=0.992\right)$, Travel to historical heritage sites $\left(\mathrm{R}^{2}=0.994\right)$, Meet people with similar interests $\left(\mathrm{R}^{2}=0.189\right)$, Go to places friends haven't been $\left(\mathrm{R}^{2}=0.161\right)$, Personal safety, even when traveling alone $\left(\mathrm{R}^{2}=0.194\right)$, Get refreshed $\left(\mathrm{R}^{2}=0.222\right)$, Relax away from the ordinary $\left(\mathrm{R}^{2}=0.269\right)$.Very low $\mathrm{R}^{2}$ values have next items: Experience solitude $\left(\mathrm{R}^{2}=0.002\right)$, Indulge in luxury $\left(\mathrm{R}^{2}=0.041\right)$; Do exciting things $\left(\mathrm{R}^{2}=0.079\right)$, Find thrills and excitement $\left(\mathrm{R}^{2}=0.001\right)$, Have fun, be entertained $\left(\mathrm{R}^{2}=0.012\right)$, Share a familiar place with others $\left(\mathrm{R}^{2}=\right.$ $0.001)$, Inspire community consciousness $\left(\mathrm{R}^{2}=0.000\right)$ and relaxation relax daily tension $\left(\mathrm{R}^{2}\right.$ 
$=0.007)$, Escape from a busy job $\left(\mathrm{R}^{2}=0.096\right)$, Feel at home away from home $\left(\mathrm{R}^{2}=0.000\right)$ has a negligible $\mathrm{R}^{2}$ raising the possibility that this item does not tap the same values dimension as the other questions.

Table 4 Squared multiple correlations

\begin{tabular}{|c|c|c|}
\hline & ITEMS & $\mathrm{R}^{2}$ \\
\hline & R.T.P & 0.000 \\
\hline \multirow{3}{*}{ EXCITEMENT } & Do exciting things & 0.079 \\
\hline & Find thrills and excitement & 0.001 \\
\hline & Have fun, be entertained & 0.012 \\
\hline \multirow[t]{3}{*}{ NOVELTY } & Experience solitude & 0.002 \\
\hline & Indulge in luxury & 0.041 \\
\hline & Experience traditional culture for their kids & 0.142 \\
\hline \multirow{2}{*}{ FAMILY } & Be together as a family & 0.224 \\
\hline & Visit places family came from & 0.151 \\
\hline \multirow{5}{*}{ LEARNING } & Explore new places & 0.844 \\
\hline & Experience new and different lifestyles & 0.987 \\
\hline & Learn new things, increase knowledge & 0.992 \\
\hline & Travel to historical heritage sites & 0.994 \\
\hline & Share a familiar place with others & 0.001 \\
\hline \multirow{4}{*}{ SOCIALIZATION } & Inspire community consciousness & 0.000 \\
\hline & Meet people with similar interests & 0.189 \\
\hline & Go to places friends haven't been & 0.161 \\
\hline & Personal safety, even when traveling alone & 0.194 \\
\hline \multirow{7}{*}{ RELAXATION } & Get refreshed & 0.222 \\
\hline & Escape from a busy job & 0.096 \\
\hline & Relax away from the ordinary & 0.269 \\
\hline & Relax daily tension & 0.007 \\
\hline & Be physically active & 0.172 \\
\hline & Feel at home away from home & 0.000 \\
\hline & Not have to rush & 0.174 \\
\hline
\end{tabular}

Source: author's research

The paper relies on related research. Park and Yoon (2009), in their article entitled Segmentation by motivation in rural tourism: A Korean case study, have proven that tourists most often travel for reasons of relaxation. Contrary to the above research, the authors concluded that there are deviations in Vojvodina, because learning is a very strong motive for going to the village. The deviation is noticed in the motive excitement because in this research, the motive is in the last place. After that, the cluster analysis performed. It was determined that the family cluster, out of four achieved clusters, carries the highest percentage of participation in the decision to visit the villages.

A similar study was conducted by Reed, Ezeuduji and Ulrike, in the paper Segmentation by motivation for rural tourism activities in The Gambia (2014). On a total sample of 430 respondents, by factor analysis, they classified the issues into four factors, of which heritage and nature has the highest factor saturations. The largest percentage of respondents come to 
spend their free time as a relaxation in nature. The research can be based on a similar one conducted in Finland. Pesonen (2012), in his research, performs a similar approach to tourist segmentation. The conclusion he comes to is that the largest number of tourists visit rural areas, in order to escape from everyday life. For all segments, the most important motivation is relaxation from the usual, closely followed by getting refreshed and a feeling of comfort. The beautiful landscape, as well as the peaceful, unhurried atmosphere are among the most important attributes of the destination for all segments.

\section{CONCLUSION}

The structure of rural settlements in Autonomus Province of Vojvodina is very heterogeneous. By villages is meant not only the most numerous with a dominant agricultural function, but also settlements that have affirmed themselves as tourist, spa, suburban, periurban settlements. Rural tourism, as a significant segment of multifunctional agriculture in Vojvodina, due to the multiplicative effect of tourism, initiates the fastest diversification of the rural economy, especially through emphasizing the production of agri-food products in the function of quality tourist nutrition in beautiful rural areas. This type of tourism is a tool to promote all kinds of resources, including even heritage conservation in all its forms. In the world, a special place is occupied by the development of all forms of rural tourism in rural areas, primarily due to the very stressful life of people in urban areas, especially in large cities. There are many motives for tourists to come to rural areas of Vojvodina. These can be: getting to know and / or participating in agricultural work, enjoying healthy nature, getting to know the ethno contents of that rural area, enjoying traditional food, wild plants, forest fruits, enjoying wine and other agri-food products, enjoying the common preparing traditional dishes with the hostess, participating in events, getting to know rural areas and their customs, especially cultural and historical heritage, introducing children to the rural area, way of life and work, hunting and fishing in specific conditions of the given rural area. Rural tourism is a common name for various activities and forms of tourism that occur outside cities, ie urban areas and those areas where mass tourism has developed. The share of the rural population in the total population of Vojvodina is very significant and amounts to $43.60 \%$. The development of tourist activity in the villages of Vojvodina began in the $70 \mathrm{~s}$ of the last century. "Initially, it was not accompanied by adequate stimulative measures, it was not given the appropriate importance. According to the authors of the Tourism Development Strategy in Vojvodina, rural tourism in 2025 will cover $6.6 \%$ of the total number of tourist nights, with an 
estimated market potential of one million nights within rural tourism, and the share of foreign guests in the total number of nights will be $15 \%$.

During the ten months of 2019, about 500,000 tourists were recorded in Vojvodina, nine percent more than in 2018 (Statistical Yearbook, 2020). The Provincial Secretariat for Economy and Tourism does not have competitions that are directly related to rural tourism in rural farms, but they provide incentives through economic entities, ie through affirmation and promotion of tourist potentials, such as those related to strengthening accommodation capacities and catering services. The current Spatial Plan of the Republic of Serbia sets longterm goals for the development and arrangement of rural areas: creating socio-economic and market conditions for accelerated economic and social development of rural areas, stopping depopulation and deteriorating demographic and social structure of rural areas, activating local potentials and raising develops and regulates the rural area as a long-term perspective and choice for life and economy, improving communal and social standards and quality of life in rural areas, ensuring economic and social security of rural households, preservation and improvement of ecological, cultural and other values in rural settlements. Projects implemented for rural tourism development in Vojvodina are the basis of implementation proposals that enable monitoring of the results of activities and the continuation of positive results of rural development of the rural population. The essence of rural development is to stop the unfavorable trends of migration of the population from rural to urban areas and the creation of new problems in overcrowded centers. Stimulating measures can not only stop the unfavorable migration trend from rural to urban areas, but also turn it in the desired direction. Motivational market segmentation is considered one of the fundamental concepts of modern marketing. Socio-demographic, socio-cultural, economic, political, environmental, and other changes have led to significant changes in its functioning, and thus to changes in the structure of demand and behavior of tourist consumers. Every business entity must adapt to the needs of consumers through the creation of such products/services, which will best meet their growing needs, and on the other hand, enable the business entity to realize its goals and make a profit (Pearce, Tan \& Schott, 2004). Today, tourists are looking for "something more" which requires an integrated approach that starts from searching for personal identity and recognizing their own comparative advantages. Much research is based on geographic and demographic variables. Thus, some research has been conducted in Serbia (Veljković \& Đorđević, 2014; Stanković, Đukić \& Popović, 2012), but many believe that traditional segmentation, with its focus on demographic and stereotypical lifestyle characteristics, is not able to provide an effective way of observing demand, ie. rural tourism needs. 
The authors of the paper conducted a survey in the villages of Vojvodina, during the period from May to October 2019, on a total sample of 491 respondents. The survey questionnaire contained 24 questions, grouped into six factors, according to the model used in their research by Park and Yoon (2009). They managed to group all items into six groups by factor analysis, and then cluster analysis to determine four groups of consumers of rural tourism product or four groups of tourist profiles. It was determined that the reason or motive for the trip was mostly relaxation. In this paper, the authors, with the help of CFA analysis, confirmed the hypothetical structure of the factors, and based on the obtained data, determined the extent to which the six factors directly affect the choice of rural tourism products. All factors have a statistical significance ranging from $\mathrm{p}<0.05$, and it is observed that they directly affect very significantly the choice of rural area for travel by tourists. Factors of relaxation (3.06), socialization (2.77), learning (8.31), family (2.76) have the highest score, while novelty (1.35), and excitement (1.00) have the lowest score.

After summarizing the Standardized Regression Weights, it is observed which motives individually affect on rural tourism. Based on these data, it can be seen that the motives grouped into factor excitement have the least influence on the choice of rural tourism, followed by the motives that make up the factor called novelty. The values of the excitement motive assessment are even negative. In the highest percentage, the motive for visiting the rural area is relaxation, which immediately constructs the profile of a rural tourist in Vojvodina.

There are no similar works on the topic of segmentation of tourist profiles at the level of Vojvodina. Still, the importance of this work and research is reflected, above all, in finding an important business segment, which is profiling existing and potential tourist consumers in rural areas of Vojvodina. The fact is that each respondent was a domestic visitor, which is the biggest limitation of this research, but certainly that the sample size can be representative for further research in the field of market segmentation and profiling of potential consumers. Thus, all entities in the development of this form of tourism will be able to create an image of corrective measures and improve tourism business in the part of the country that is rich in the rural resource base. Based on the research data and the obtained results, it will be possible to see the real situation and possibilities of rural tourism development in this part of the country. Accordingly, it is possible to conduct similar and broader research on a given topic and to construct strategic plans for the future development of rural tourism. According to Middleton (2002), such research can serve to facilitate marketing and presentation of the destination to specific groups of consumers. The negative consequences of the Covid-19 pandemic will be 
felt in all areas of the economy, including rural tourism. Further research in rural tourism will be limited. It will be necessary to start from the zero point of business, to attract tourists, with old and new strategies and ideas, which can certainly rest on the basis of this research and the similar research.

\section{Acknowledgments}

The research was supported by Ministry of Education, Science and Technological Development, Serbia (Grant No. III 47007); and from RUDN University in Program 5-100 in Russian Federation.

\section{REFERENCES}

Andrić, N., Tomić, D., and Tomić, G. (2010). Status and perspectives of development of rural tourism in the autonomous province of Vojvodina. In: Junancic, L., (ed.) Proceedings of the 118th EAAE Seminar Rural development: governance, policy design and delivery. Ljubljana: Biotechnical Faculty, Zootechnical Department, Book of proceedings, 611621.

Bansal, H., \& Eiselt, H. (2004). Exploratory research of tourist motivations and planning. Tourism Management, 25, 387-396.

Beane, T. P., \& Ennis, D. M. (1987). Market segmentation: a review. European Journal of Marketing, 21(5), 20-41.

Blešić, I., Pivac, T., Besermenji, S., Ivkov-Džigurski, A., \& Košić, K. (2014). Residents' Attitudes and Perceptiontowards Tourism Development: A Case Study of Rural Tourism in Dragacevo, Serbia. Eastern European Countryside, 20, 151-166.

Cánoves, G., Villarino, M., Priestley, G. K., \& Blanco, A. (2004): Rural tourism in Spain: An analysis of recent evolution. Geoforum 35(6),755-769.

Carter, L. H., Wei, R.W., S., \& Ruys, H. (2002). Profiling the senior traveller: An Australian perspective. Journal of Travel Research, 41, 23-37.

Cha, S., McCleary, M., \& Uysal, M. (1995). Travel motivations of Japanese overseas travelers: a factor-cluster segmentation approach. Journal of Travel Research, 33(2), 33-39.

Çiğdem, K. A., Tülay, C. T., \& Ferah, Ö., \& Hasan, T. (2020). Land use suitability analysis of rural tourism activities: Yenice, Turkey. Tourism Management, 76, February 2020, 103949.

Cohen, E. (1975).Who is a tourist? A conceptual clarification. Sociological Review, 6,408424.

Crompton, J. L. (1979). Motivation for pleasure vacation. Annals of Tourism Research, 6, 408- 424.

Cvijanović, D., Gajić, T., (2020). Analysis of the Market Values of Lemeska spa; Importance and Possibility of Renewal Through the Cluster System. Sustainable Agriculture and Rural Development in Terms of the Republic of Serbia Strategic Goals Realization Within the Danube Region. Thematic Proceedings. Institute of Agricultural Economics Belgrade,177-193.

Dann, G. M. (1981). Tourism motivations: an appraisal. Annals of Tourism Research, 8(2), $189-219$.

Dissard JC., Aubert F., Truchet S. (2009). An estimation of tourism dependence in French rural areas, in Matias A., Nijkamp P., Sarmento M. (eds.), Advances in Tourism Economics, Springer, 273-294. 
Ezeuduji, I. O., \& Rid, W. (2011). Rural tourism offer and local community participation in The Gambia. TOURISMOS, 6(2), 187-211.

Flisher, A., \& Felsenstein, D. (2000). Support for rural tourism: Does it make a difference? Annals of Tourism Research, 21(4).180-194.

Fodness, D. (1994). Measuring tourist motivation. Annals of Tourism Research, 21(3), 555581.

Formica, S., \& Uysal, M. (1998). Market segmentation of an international culturalhistoric event in Italy. Journal of Travel Research, 36(4), 16-24.

Frochot, I. (2005). A benefit segmentation of tourists in rural areas: a Scottish perspective. Tourism Management, 26, 335-346.

Gajić, T., Penić, M., Vujko, A., \& Petrović, M.D., (2018). Development Perspectives of Rural Tourism Policy - Comparative Study of Rural Tourism Competitiveness Based on Perceptions of Tourism Workers in Slovenia and Serbia. Eastern European Countryside, 24, (1),144-154.

Gajić, T., Vujko, A., Petrović, M.D., Mrkša, M., Penić, M. (2018). Examination of regional disparity in the level of tourist offer in rural clusters of Serbia. Economic of agricultureEkonomika poljoprivrede, Vol.65(3),911-929.

George, D., \& Mallery, P. (2003). SPSS for Windows step by step: A simple guide and reference, 11.0 update (4th ed.). Boston, Allyn \& Bacon.

Hall, D.R., Roberts, L. and Mitchell, M. (2003). New Directions in Rural Tourism: Local Impacts, Global Trends, Hants, Ashgate Publishing.

Hanqin, Z., \& Lam, T. (1999). An analysis of Mainland Chinese visitors' motivations to visit Hong Kong. Tourism Management, 20, 587-594.

Iso-Ahola, S. E. (1982). Towards a social psychology theory of tourism motivation. Annals of Tourism Research, 9, 256-262.

Jang, S., \& Wu, C.-M. E. (2006). Seniors' travel motivation and the influential factors: an examination of Taiwanese seniors. Tourism Management, 27, 306-316

Johns, N., \& Gyimothy, S. (2002). Market segmentation and the prediction of tourist behaviour: the case of Bornholm, Denmark. Journal of Travel Research, 40(3), 316327.

Jing, G., \& Bihu, W., (2018). Revitalizing traditional villages through rural tourism. A case study of Yuanjia Village, Shaanxi Province China, Tourism Management, 63, 223-233.

Jing X. (2006). Rural Tourism and Sustainable Community Development, International Forum on Rural Tourism, China, 4.-6- September 2006, Final Report World Tourism Organization

Josiam, B., Mattson, M., \& Sullivan, P. (2004). The historaunt: heritage tourism at Mickey's dining car. Tourism Management, 25, 453-461

Kelliher, F., Reinl, L., Johnson, G.T., \& Joppe, M. (2018). The role of trust in building rural tourism micro firm network engagement: A multicase study, Tourism Management, 68, pp.1-12.

Kim, S., \& Lee, C. (2002). Push and pull relationships. Annals of Tourism Research, 29(1), $257-260$.

Kozak, M. (2002). Comparative analysis of tourism motivations by nationality and destination. Tourism Management, 23, 221-232.

Lane, B., Kstelhoz, E., (2015). Rural tourism: the evolution of practice and research approaches - towards a new generation concept? Journal of Sustainable Tourism, 23, 1133-1156.

Lee, C., Lee, Y., \& Wicks, B. E. (2004). Segmentation of festival motivation by nationality and satisfaction. Tourism Management, 25, 61-70 
Loker-Murphy, L. (1996). Backpackers in Australia: a motivation-based segmentation study. Journal of Travel and Tourism Marketing, 5(4), 23-45.

Loker-Murphy, L., \& Perdue, R. (1992). A benefit-based segmentation of a nonresident summer travel market. Journal of Travel Research, 31(2), 30-35.

Mok, C., \& Iverson, T. J. (2000). Expenditure-based segmentation: Taiwanese tourists to Guam. Tourism Management, 21, 299-305

Molera, L., Albaladejo, I.P. (2007). Rural tourism demand by type of accommodation. Tourism management 28 (3), 757-767.

Moscardo, M., (2004). Shopping as a Destination Attraction An Empirical Examination of the Role of Shopping in Tourists' Destination Choice and Experience.Journal of Vocation Marketing, 10(4), 294-307.

Nicholson, R., \& Pearce, D. (2001). Why do people attend events: a comparative analysis of visitor motivations at four south island events. Journal of Travel Research, 39, 449-460

Novković, N., Mutavdžić, B., \& Vukelić, N. (2013). Vojvodina's agriculture-analysis \&

possibilities. The Seminar Agriculture and Rural Development - Challenges of Transition and Integration Processes, Department of Agricultural Economics, Faculty of Agriculture, University of Belgrade, Book of proceedings ,90-97

Oh, H., Uysal, M., \& Weaver, P. (1995). Product bundles and market segments based on travel motivations: a canonical correlation. Annals of Tourism Research, 6, 195-197

Yuan, S., \& McDonald, C. (1990). Motivational determinates of international pleasure time. Journal of Travel Research, 29(1), 42-44.

Park, D. B. and Y. S. Yoon. (2009). Segmentation by Motivation in Rural Tourism: A Korean Case Study. Tourism Management 30, 99-108.

Pearce, P., \& Lee, U. L. (2005). Developing the travel career approach to tourist motivation.

Journal of Travel Research, 43, 226-237.

Pesonen, J.A., \& Tuohino, A. (2013). Activity-based market segmentation of rural well-being tourists: Comparing online information search. Journal of Vacation Marketing, 23(2), 226-237.

Pesonen, J.A. (2012). Segmentation of rural tourist combinating push and pull factors. Tourism and Hospitality Management, 18 (1), pp. 69-82,

Petrović, M., Vujko, A., Gajić, T., Vuković, D., Radovanović, M., Jovanović, J., \& Vuković, N. (2018). Tourism as an Approach to Sustainable Rural Development in Post-Socialist Countries: A Comparative Study of Serbia and Slovenia.Sustainability, 10(54), 2-14.

Petrović, M., Blešić, I., Vujko, A., \& Gajić, T. (2017). The role of agritourism impact on local community in a transitional society: a report from Serbia. Transylvanian Review of Administrative Sciences, 50, 146-163.

Rid, W., Ezeuduji, U., \& Probstl-Haider, I (2015). Segmentation by motivation for rural tourism activities in The Gambia. Tourism Management, Vol.40, 102-114.

Roberts, L., \& Hall, D. (2001). A sideways look at tourism demand. Rural tourism and recreation: principles to practice. New York: CABI Publishing, 128-146

Sarigollu, E., \& Huang, R. (2005). Benefits segmentation of visitors to Latin America. Journal of Travel Research, 34, 277-293.

Song, D. Y. (2005). Why do people visit the countryside? Push \& pull factors. Journal of Green Tourism, 12(2), 117-144.

Sharpley, R. (2000). The consumption of tourism revisited. In M. Robinson, P. Long, M. Evans, R. Sharpley, \& J. Swarbrooke (Eds.), Reflections on international tourism. Motivations, behaviour and tourist types, 381-391.

Scott, Noel R. and Parfitt, Nick (2004). Lifestyle Segmentation in Tourism and Leisure: Imposing order or finding it?. Hospitality, tourism, and lifestyle concepts . Haworth Hopitality Press, 121-139. 
Snyman, S. L. (2012). The role of tourism employment in poverty reduction and community perceptions of conservation and tourism in southern Africa. Journal of Sustainable Tourism, 20(3), 395-416.

Uysal, M., \& Jurowski, C. (1994). Testing the push and pull factors. Annals of Tourism Research, 21(4), 844-846.

Walker, J., Courneya, K.S., Deng, J. (2006). Leisure constraint theory and sport tourism. Journal of Leisure Research 38 (2), 224-248.

Wight, P. A. (1996). North American ecotourism markets: motivations, references, and destintions. Journal of Travel Research, 35(1), 3-10

Zhang, H. Q., \& Lam, T. (1999). An analysis of Mainland Chinese visitors' motivations to visit Hong Kong. Tourism Management, 20, 587-593.

Zhang, D., Ritchie, W.B., Benckendorff, P.J., \& Bao, J. (2019). Emotional responses toward Tourism Performing Arts Development: A comparison of urban and rural residents in China. Tourism Management, 70, pp. 238-249. 